\title{
CHARACTERIZATION OF TRAIN BRAKE-BLOCKS COMPOSITE REINFORCED WITH ALUMINUM-DROSS
}

\author{
E. O. Obidiegwu ${ }^{1, *}$, H. E. Mgbemere ${ }^{2}$, E. F. Ochulor ${ }^{3}$ and P. A. Ajayi ${ }^{4}$

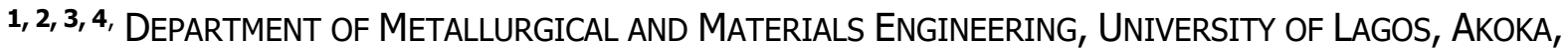 \\ LAGOS STATE, NIGERIA \\ E-mail addresses: ${ }^{1}$ eobidiegwu@unilag.edu.ng, ${ }^{2}$ hmgbemere@unilag.edu.ng, \\ 3 eochulor@unilag.edu.ng, ${ }^{4}$ ajayipaul5588@yahoo.com
}

\begin{abstract}
Brake blocks are usually made from asbestos, metals and ceramics. It has been realised that asbestos discharges dangerous gases which can be harmful. This problem necessitated the search for human-friendly materials. Therefore, this paper studies the production and characterization of train brake blocks produced from clay reinforced with aluminum dross. This was done by producing samples of composite using clay from a deposit at Osiele and aluminum dross from Tower Rolling Mill Otta, both in Ogun state. The percentage composition of aluminum dross was varied from $0 \%$ to $25 \%$ to produce brake samples. Their wear rate, tensile strength, compressive strength, hardness, thermal conductivity and microstructure were analysed. The results from this project such as UItimate tensile strength (UTS) of 7.4Mpa, Impact energy 6.92J, Hardness $28.8 \mathrm{HV}$, wear rate $0.0071 \mathrm{~g} / \mathrm{sec}$ and thermal conductivity of 0.01075 indicate that, with $5 \%$ aluminium dross it is possible to develop brake block that exhibits property recommended by Rail Industry Safety and Standard Board (RISSB).
\end{abstract}

Keywords: Train, Brake blocks, Clay composite, Aluminum Dross, Mechanical properties.

\section{INTRODUCTION}

The purpose of braking action in train, is to perform controlled reduction in velocity of the train, either to reach a certain lower speed or to stop to a fixed point. In general terms, this happens by converting the kinetic energy of the train and the potential one into mechanical work of braking forces which usually turns into heat, which dissipates into the environment [1].

Rail transport system is a very important sector of any society because not only do they serve as an affordable means of transportation to so many people on a daily bases, they are also used for transportation of raw materials and bulky goods. A track record of poor maintenance of train systems put the safety of passengers in jeopardy. This record of poor maintenance must be addressed by ensuring that the braking systems of these trains are up to standard [2].
Brake block materials were typically made with asbestos, metals, and ceramic materials. It is commonly realized that asbestos discharges dangerous gases which can be harmful to human well-being. This prompts the search for humanfriendly materials. Thus, clay and aluminium dross. Another common problem with brake block is known as brake fade. This is the main cause of several derailments of trains that have happened over the years. Brake fade occurs when the brake block and the brake rotor no longer generate sufficient mutual friction to stop the vehicle at its preferred rate of deceleration. Often resulting in increased stopping distances, and fatal consequences, leading to train derailment. Most of the brake blocks currently used in Nigeria are imported.

In order to manage this challenge effectively, there is a need for the production of brake block that is safer, without any health implications and more 
effective brake that do not wear out fast. Hence, this is the aim of this research.

Due to the magnitude of friction and heat generated during the braking process and its wear effect on the brake block, serious consideration must be put in place for continuous replacement of worn out blocks. Thus, the braking system must be completely modelled in a way that it can withstand the actions of excessive heat and wear [3].

The standard characteristics requirements for a conventional brake block include wear resistance, lightweight, long life, low wear rate, low thermal conductivity, low cost of production and less noise [4]. Composite blocks have become the preferred choice in recent years. Various types of composite brake blocks have been introduced over the years, and in most cases, they are known to outperform the conventional cast iron blocks in almost all applications [5]. Brake block friction materials comprise of various added substances to make it function the way it ought to.

Friction materials such as brake blocks are to decelerate a vehicle by converting kinetic energy to heat via friction. Therefore, any vehicle which uses the action of a brake pad rubbing on a brake rotor to convert the vehicle's kinetic energy into heat has the potential to develop brake fade [6].

Clay, which is normally used as a refractory material, due to its high melting point or high refractoriness, which is closely related to thermochemical stability can be a suitable material to function properly under such conditions.

Many studies have been carried out in order to improve the wear resistance of train brake blocks. In this paper, some recent studies on brake blocks are discussed briefly with a view to understand the current trend of the discipline:

The suitability of Carbon fibre reinforced SiC composites for the manufacture of brake blocks was investigated [7]. The brake block was made by hot forming and friction wear test was carried out on it. They discovered that as temperature increased, the wear rate of the produced brake block increased. This discovery as well as the high cost of obtaining carbon fibre made the composite unsuited for commercial production.

In a paper [8], they developed composites with 1525 wt. \% clay addition which were similar to conventional semi-metallic brake pad in terms of wear and friction properties. This shows that the use of clay in the production of brake block fiction material is industrially productive.
In another publication [9, 10], the analysis of Aluminum matrix composite for use as brake block material may result in a new patent for friction materials applied in the vehicle brake pad. In an experiment, reinforced epoxy composites were prepared by open mould resin casting method. The results revealed a minimal specific wear rate and coefficient of friction with higher mechanical properties with the use of Epoxy compared to other resins.

A research on the characterization of train brake blocks was carried out [11]. Their metallurgical characterization consisted of a study of the hardness and microstructural analysis of the different samples prepared using cast iron. The results show that the hardness of some soles is greater than that of the wheel, mainly associated with a cementite microstructure. This can lead to a premature wear of the wheels at the expense of brake blocks.

The gap from the literature is that most of the researchers do not harness industrial waste which can help to reduce environmental pollution. Therefore, this research will employ Clay and aluminum dross as the principal materials. Polyamide Epoxy and epoxy hardener are employed as additive materials. Unlike other popularly used resins materials, from a review of its past application, it has proven to be suitable for application in this current study.

The objective of this research is to develop an alternative, high quality and cheaper composite brake blocks friction material that can be locally used to produce train brake systems in Nigeria.

\section{MATERIALS AND METHODS}

Clay was obtained from a deposit at Osiele in Ogun State. It was crushed and dried to fine particles of about 150 to $200 \mu \mathrm{m}$ with the use of grinding machine. The clay was crushed and allowed to dry in the furnace to expel organic materials and clay serves as the matrix in this study. Aluminum Dross obtained from Tower Rolling Mill in Otta area of Ogun state was also crushed to fine particles of about 150 to $200 \mu \mathrm{m}$ with the use of a grinding machine. The Aluminum dross serves as the filler material in this study. Clay and aluminum dross of of 150 to $200 \mu \mathrm{m}$ and $0-25 w t \%$ were used based on prior experiment. A liter of Polyamide Epoxy resin and Epoxy Hardener was obtained from the local Technical store in Lagos Nigeria.

For the control sample $100 \mathrm{~g}$ of clay was measured with $50 \mathrm{~g}$ of epoxy and $25 \mathrm{~g}$ of epoxy hardener. The 
ratio of epoxy and epoxy hardener used was varied before a suitable quantity of both was established at $50 \mathrm{~g}$ and $25 \mathrm{~g}$ respectively, which was constant for all other brake block samples produced. The ratio of clay and aluminum dross was then varied from $75 \mathrm{~g}$ to $100 \mathrm{~g}$ and $0 \mathrm{~g}$ to $25 \mathrm{~g}$ respectively. The variation of the Aluminum dross in the composite material was simulated from the chemical composition analysis of commercially used brake block.

A wooden mould was acquired for the casting of samples in various sizes and shapes for various tests carried out. The dimension of each test sample was acquired from various test centers and integrated into the cast process. Paper tape was used as liners to help ease the removal of the samples after solidification. The measured and thoroughly stirred mixture of clay, aluminum dross, epoxy and epoxy hardener was poured into the prepared mould and allowed to solidify for $24 \mathrm{hrs}$ at room temperature. Finally, various tests such as hardness, wear rate, friction, impact, tensile and compressive strength tests were carried out.

Tensile and compression test was carried out according to ASTM A-370, with computerized Universal Testing Machine (UTM) (Instron Electromechanical Testing systems) Model 3369 equipped with a $50 \mathrm{kN}$ load cell and data analysis software programmer at the Material Testing Laboratory of the Centre for Energy Research and Development, Obafemi Awolowo University, Ife., This system features an automatic results screen showing all relevant parameters from International Standards. Hardness test was carried out according to ASTM D2240, using Micro Hardness Tester (MMTX7A) at Material and Metallurgy Engineering department of University of Lagos, Akoka, Lagos state, Nigeria.

The friction-wear test was carried out according to ASTMG 99 standard, using the dry wear testing method. It was carried out at Materials science and engineering department of University of Ile-Ife, Osun state, Nigeria; using the following steps on Pin-OnDisc testing machine. Thermal Conductivity was carried out According to the ASTM C 1114-98 standard.

Microstructural examination of the samples was also carried out. SEM analyses were performed with Oxford Phenom-Prox SEM at ABU, Zaria to observe the morphology and size of the Clay Al-dross specimens. The sample was observed using an accelerated voltage of $15 \mathrm{KV}$. While the EDS analysis of the Clay Al-dross specimens were determined with Xsupreme800 Phenom-world at ABU, Zaria at specification of FOV: $269 \mu \mathrm{m}$, Mode: 15kV - Image, Detector: BSD Full, for all samples.

\section{RESULTS AND DISCUSSION}

\subsection{Chemical Composition Analysis}

The ED-XRF of the aluminum dross was carried out using an XRF machine model; EDX - 720 X-ray Florescence spectrum according to ASTM D 1646. The result is presented in Table 1.

The results of the ED-XRF (Table 1 ) revealed that the major constituent of Aluminium dross is aluminium oxide $(77.72 \%)$. Aluminum oxide is very resistant to high temperature, this will help the brake block to withstand high temperature generated during service. It also contains reasonable amount of silica $\left(\mathrm{SiO}_{2}\right)$. This serves as a frictional material which will help to improve the thermochemical stability of the brake block. There are traces of iron oxide, titanium and calcium oxide. These will help to improve the hardness of the brake block.

\subsection{Mechanical Properties}

\subsubsection{Tensile Test}

It was observed from the result in Figure 1 that sample A with $5 \%$-Al dross has the highest Ultimate Tensile strength of $7.407 \mathrm{MPa}$, followed by the sample C with $15 \%$-Al dross (5.069 $\mathrm{MPa})$, then sample D with $20 \%$-Al dross (3.988 MPa) and sample E with $25 \%$-Al dross (2.558 MPa). This could be as a result of the formation of adequate solid solution at $5 \% \mathrm{Al}$ dross. The tensile test result shows a decrease in UTS, as the Al-dross content increase. This could be as a result of super saturation of Al which takes place after $5 \%$ addition.

The tensile and fracture (breaking) strengths are also higher for sample A compared to others as depicted in Figure1.

\subsubsection{Compression Test}

The compression test result presented in Figure 2 shows that the control sample with $100 \%$-Clay content has the highest compressive value, this might be due to homogeneity of the sample, since it is produced from clay alone. This ascertains the fact that clay has a good compressive strength. While sample A and B have the lowest compressive value. Which can be as a result of the poor compressive strength of Al. 
Table 1: Chemical composition analysis result of Al-dross from ED-XRF

\begin{tabular}{lllllll}
\hline Analyte & $\mathrm{Al}_{2} \mathrm{O}_{3}$ & $\mathrm{SiO}_{2}$ & $\mathrm{Fe}_{2} \mathrm{O}_{3}$ & $\mathrm{CaO}$ & $\mathrm{TiO}_{2}$ & L. I. O \\
\hline Result & $77.721 \%$ & $10.450 \%$ & $4.365 \%$ & $3.578 \%$ & $1.344 \%$ & $2.542 \%$ \\
\hline
\end{tabular}

\subsubsection{Impact Test}

The impact test result shown in Figure 3 revealed Sample A with 5\%-Al dross content has the highest impact strength, following a similar trend that was observed in the tensile test result. This is an indication that $5 \% \mathrm{Al}$ dross is required to improve the impact strength. A fluctuating pattern of decrease in impact strength of the composite with increasing $\mathrm{Al}$ wt.\% content is also observed, while sample E with $25 \%$ Al-dross content has the lowest impact strength compared to other samples.

It should also be noted that the control with no Aldross content also exhibited a relatively high impact strength. This could be as result of perfect bonding between the homogeneous particles of clay.

\subsubsection{Hardness Test}

The hardness test result shown in Figure 4 produced a changed pattern in the trend of result. Sample E with highest Al-dross content has the highest hardness property unlike the previous trends where it gave lowest values. This indicates that Al dross can improve the hardness of the material. While sample A came in with the second highest hardness value that is still within the recommended value of hardness.

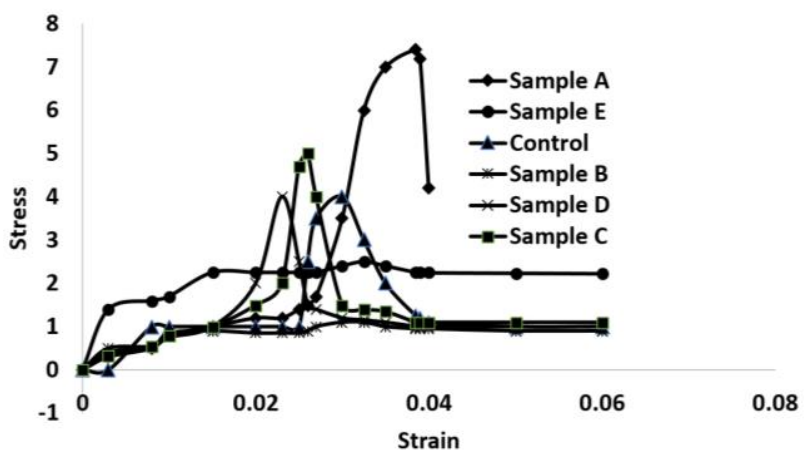

Figure 1. The tensile stress-strain graph

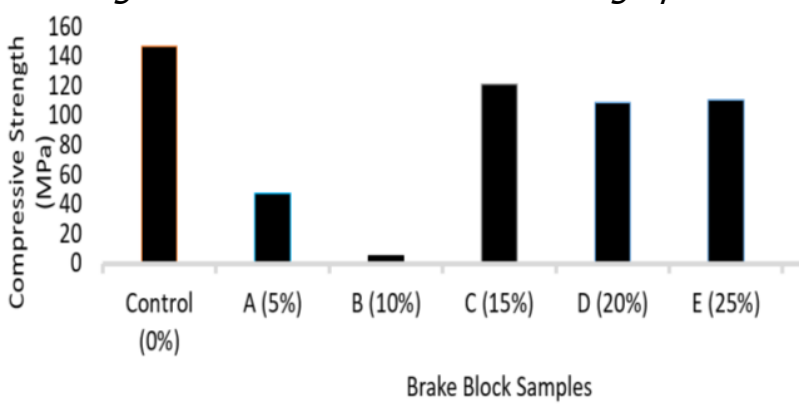

Figure 2: Compressive strength of brake blocks with different amount of aluminium dross

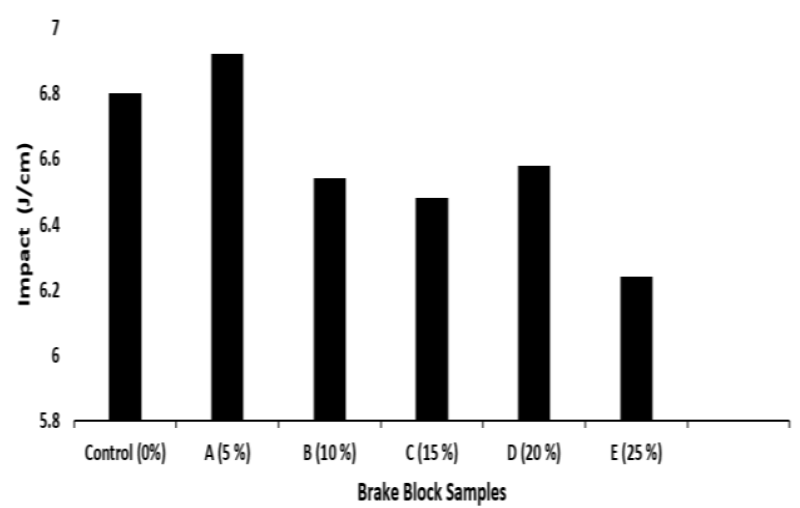

Figure 3: Impact energy of various samples

\subsubsection{Wear Rate}

The results shown in Figure 5, indicate that Sample A with $5 \%$ Al-dross has the lowest wear rate value, which indicates that it is the sample with the lowest rate of volume loss per unit load.

Samples B, C, D, and E indicates a pattern of decreasing wear rate with increase in the Al wt\% content. The control sample with $100 \%$ clay content exhibits a relatively lower wear rate value compared to sample B, C, D. Considering the area of application of this project that requires minimum wear rate, sample A showcase the best wear rate property, also similar to that of the conventional brake block material with standard of about $5 \% \mathrm{Al}$ content.

\subsubsection{Friction Test}

The results of the friction coefficient are shown in Figure 6 . The friction coefficient of modern brake pads should be low enough to prevent locking of the wheels but high enough to provide sufficient stopping power. Friction coefficients of the conventional brake blocks are typically between 0.25 and 0.58 . Sample B with $0.27 \mu$ and sample E with $0.26 \mu$ have the closest coefficient of friction as recommended by the Rail Industry Safety and Standard Board (RISSB).

\subsection{Thermal Conductivity}

From the thermal conductivity result shown in Figure 7, it is observed that sample $A$ has the highest thermal property, when all composite samples were subjected to similar thermal conditions. The control sample has a better thermal 
value compared to all other samples containing Aldross, with the exception of sample $A$ that has $5 \%$ Al-dross content. It has the thermal property recommended by RISSB.

\subsection{Microstructure Examination}

The microstructure image presented in Figures 8 13 with magnification of $500 x$ reveals the structure of the materials. The microstructure reveals that the brake block is composed of a number of phases, some of which appear to be metallic (Al-dross) in nature while others appear to be inorganic (clay). To confirm the phases present, the EDX was further carried out. This indicates that silica is the most prominent portion in Figure 8, as can be seen from the highest peak in EDX. To be very sure, detailed analysis, ED-XRF was also carried out as shown in Figure 9, this shows the phases and compound present. The most common elements found were, $\mathrm{Si}, \mathrm{Al}, \mathrm{C}, \mathrm{Fe}, \mathrm{Mn}, \mathrm{Ti}, \mathrm{K}, \mathrm{Ca}, \mathrm{V}, \mathrm{Cr}$, and $\mathrm{Zn}$.



Figure 4: Variation of Hardness with the composition of Al-dross



Figure 5: Effect of addition of Al-dross on the wear rate of the samples

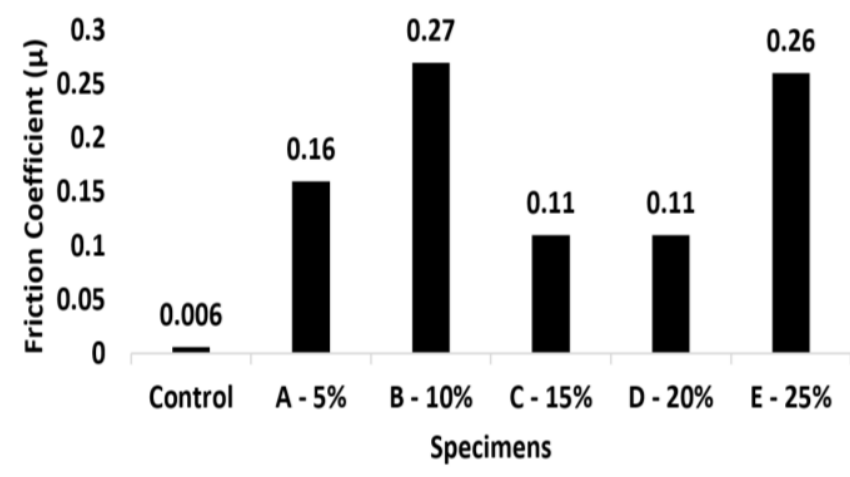

Figure 6: Effect of addition of Al-dross on the friction coefficient of samples

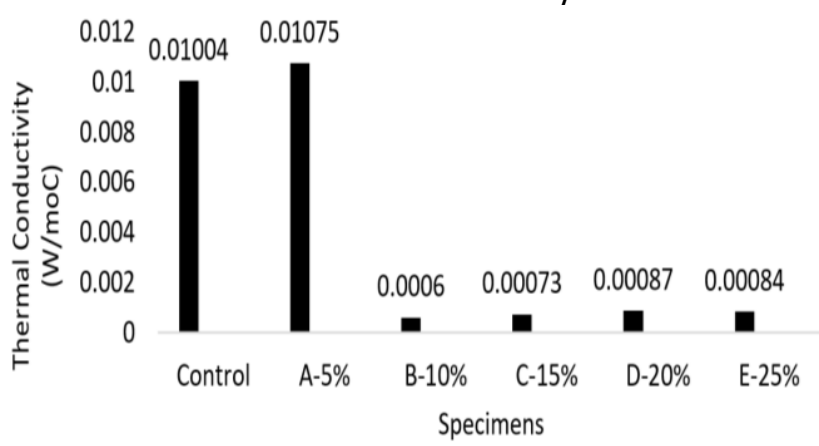

Figure 7: Effect of addition of Al-dross on thermal conductivity of the samples.
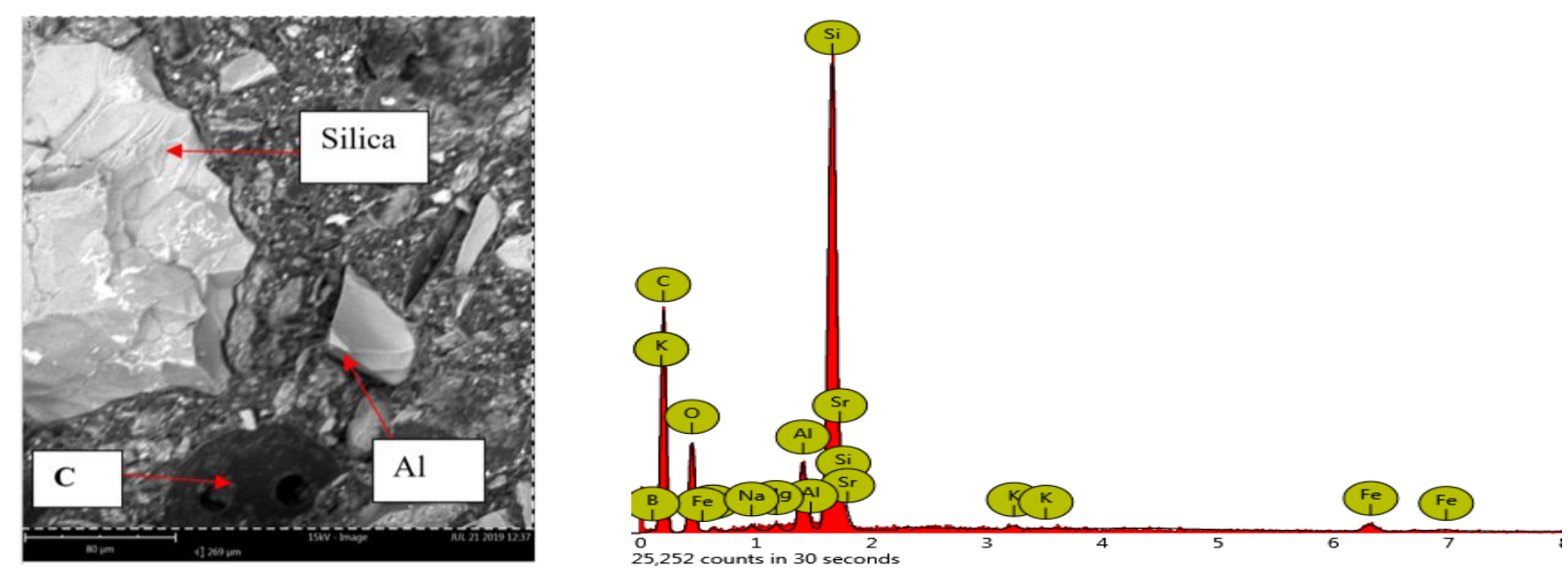

Figure 8: Microstructural distribution of the control composite sample with its EDX 
Figure 10 is the Micrograph of Sample A containing $5 \%$ Al-Dross. From the figure, the phases are more uniformly distributed. This could be the reason sample A has better properties than other samples.
The SEM Micrograph and EDX of Sample B with $10 \%$ Al-Dross and $90 \%$ clay are shown in Figure 11. The Microstructure revealed that the Phases are not uniformly distributed and this could be the reason some of sample $B$ results are poor.



[Note]

Figure 9: ED-XRF of control composite sample.


Figure 10: SEM Micrograph of sample A containing 5\% Al-Dross with its EDX.


Figure 11: The SEM Micrograph and EDX of sample B containing $10 \%$ Al-Dross. 
From Figure 12, the micrograph revealed that there are different phases which are uniformly distributed. For more detailed comparison ED-XRF was carried out on sample $E$, as shown in Figure 13.

\section{CONCLUSION}

The results obtained from this research indicate that it is possible to develop composite brake block friction material using clay reinforced with aluminum dross material. Some samples produced from the materials exhibit properties required for a train brake system. Sample A with 5\% aluminum dross had the highest UTS and impact strength, moderate hardness and thermal conductivity values, and the lowest wear rate. A trend of decrease in mechanical properties with respect to increasing Al-dross content of the composite samples is noticed. Suggesting that Aluminum dross higher than $5 \mathrm{wt} \%$ in Clay-Al composite material will reduce the overall mechanical properties of the composite. Samples A with $5 \%$ Al-dross is seen to have overall better mechanical properties which is similar to that of conventional train brake block materials that satisfy the requirements specified by the Rail Industry Safety and Standard Board.


Figure 12: SEM Micrograph and EDX of the sample E containing $25 \%$ Al-dross.



[Note]

Figure 13: ED-XRF of sample $E$ 


\section{REFERENCES}

[1] Cruceanu C. "Train braking, reliability and safety in railway", Dr. Xavier Perpinya (Ed.), ISBN: 978-953-51-0451-3, InTech, Available from: http://www.intechopen.com/books/reliabilit y-and-safety-inrailway/braking-systems-forrailway-vehicles, Accessed on January 24, 2020

[2] Vernersson T. Lund R. Abbasi S. and Olofsson U. "Wear of railway brake block materials at elevated temperature". www.researchgate. Net/publication/236680720, Accessed on August 12, 2019

[3] Akinlabi E.T., Sanusi K.O., Mamabolo M. "Characterising the brake blocks of a freight rail container wagon". Proceedings of the world Congress on Engineering (WCE), London U.K. Vol. II, June 29 - July 1, 2016.

[4] Belgian Railways, "Basics of pneumatic brakes," Retrieved online at: http://www.adameurope. Accessed on July 18, 2018

[5] Gupta M. L., Singh P. N., Gupta K. K., and Arora A. Air Brake System, in Maintenance Manual for Wagons, New Delhi, Indian Railways, 2001.

[6] Shubham W., Akash M., Nikhil G., Prafulla B., Nitin G., Krunal K. "An analysis for improving performance of train brake pad by using cad and cae software", International Research Journal of Engineering and Technology (IRJET), Vol. 4, issue 10, 2017, pp. 1174 1175.

[7] Byeong-Choon G, In-Sik C. "Microstructural analysis and wear performance of carbon fibre reinforced SiC composites". Materials (Basel), Vol. 10, Number 7, 2017, pp. 701.

[8] Agbeleye, A., Esezobor, D., Balogun, S., Agunsoye, J., Solis, J., Neville, A., "Tribological Properties of Aluminium-Clay composites for brake disc rotor applications", Journal of King Saud University - Science. Vol. 32, issue 1, 2020, pp. 21 - 28.

[9] Allazadeh, M., Balazsi, C., "Reinforced Aluminum Matrix Composite Application in Friction Material". Recent Patents on Corrosion Science. Vol. 3, issue 1, 2013, pp. $39-46$.

[10] Shivamurthy, B., Murthy, K., Peter. C. J., Kabir, R., Bhat, B., Anandhan, S. "Mechanical Properties and Sliding Wear Behavior of Jatropha Seed Cake Waste/Epoxy Composites". Journal of Material Cycles and Waste Management. Vol. 17, 2014, pp. 144156.

[11] Fall, M., Niang, F., Hubert, O. and Ndiaye, M.B. "Metallurgical analysis of brake blocks". Open Journal of Metal, Vol. 7, 2017, pp.1-8. 